\begin{tabular}{|ll|l|}
\hline Submitted $:$ 2020-11-27 & Accepted : 2021-04-21 \\
\hline Revised $:$ 2021-06-26 & Published $:$ 2021-07-01 \\
\hline
\end{tabular}

\title{
Theory of Learning Humanism and Its Implications in Arabic Language Learning
}

\author{
A. Syahid Robbani ${ }^{1}$; Ahmad Muzayyan Haqqy ${ }^{2}$ \\ ${ }^{1}$ State Islamic University of Sunan Kalijaga Yogyakarta, Indonesia \\ ${ }^{2}$ State Islamic University of Mataram, Indonesia \\ 1'syahidrobbani5@gmail.com, 2muzayyan.haqqy@gmail.com
}

\begin{abstract}
Abstrak
Belajar merupakan suatu proses/usaha/aktivitas yang dilakukakan oleh individu dengan tujuan untuk memperoleh perubahan kepribadian atau tingkah laku. Proses pembelajaran yang ada saat ini terkesan seperti seorang guru yang mengisi gelas kosong, ataupun seperti seorang ibu yang menyuapi anaknya makanan. Teori belajar humanisme muncul dengan tujuan agar peserta didik mampu menjadi individu yang bertanggung jawab, penuh perhatian terhadap lingkungannya, serta memiliki kedewasaan emosi dan spiritual. Artikel ini merupakan kajian kepustakaan dan menggunakan metode deskriptif kualitatif serta mencoba mengkaji teori belajar humanisme dan implikasinya dalam pembelajaran bahasa Arab. Hasil kajian menunjukkan bahwasanya teori belajar humanisme dapat diterapkan dengan merumuskan tujuan pembelajaran yang jelas, mengusahakan partisipasi aktif dari peserta didik, mendorong peserta didik untuk berpikir kritis dan berani mengungkapkan pendapat, serta bagaimana seorang guru dalam proses pembelajarannya mencoba memahami jalan pikiran peserta didik dan memberikan mereka kesempatan. Dan dengan diterapkannya teori belajar humanisme, siswa diharapkan mampu menjadi individu yang memiliki kemampuan akademik serta akhlak yang baik sehingga di kemudian hari akan mengurangi problematika dan penyimpangan-penyimpangan sosial yang ada; mampu mengembangkan
\end{abstract}


A. Syahid Robbani; Ahmad Muzayyan Haqqy

kemampuannya baik dari sisi kognitif, afektif, maupun psikomotorik serta menjadi individu yang bertanggung jawab dan memiliki kedewasaan emosi serta mampu mengaktualisasi diri; siswa menjadi lebih termotivasi untuk memperoleh keterampilan baru, kecakapan dan pengetahuan yang lebih luas dalam pembelajaran bahasa Arab.

Kata kunci: teori belajar, humanisme, implikasi, pembelajaran bahasa Arab

\begin{abstract}
Learning is a process/effort/activity carried out by the individual to obtain a change in personality or behavior. The current learning process seems like a teacher filling an empty glass, or like a mother feeding her child food. The theory of learning humanism arises with the aim that learners can become responsible individuals, attentive to their environment, and have emotional and spiritual maturity. This article is a literature study and uses qualitative descriptive methods and tries to examine the theory of humanism learning and its implications in Arabic language learning. The results showed that humanism learning theory can be applied by formulating clear learning objectives, working on the active participation of learners, encouraging learners to think critically and dare to express opinions, and how a teacher in the learning process tries to understand the learner's way of thinking and give them an opportunity. And with the implementation of the theory of humanism learning, students are expected to be individuals who have good academic ability and morals so that in the future will reduce the problems and social deviations that exist; able to develop their abilities both in terms of cognitive, affective, and psychomotor as well as being responsible individuals and having emotional maturity and being able to actualize themselves; students become more motivated to acquire new skills, skills and wider knowledge in Arabic language learning.
\end{abstract}

Keywords: theory of learning, humanism, implications, learning Arabic 


\section{A. Introduction}

Learning is an obligation that must be done by everyone, especially for Muslims. By learning, one can gain knowledge, knowledge, and broader insights. In the context of studying in a formal institution, a student will be directed and guided by the educator. The learning process that takes place between students and educators does not have to be like an empty glass filled, not always like a mother feeding her baby food. But between students and educators should play an active role because learning is essentially an interaction between educators and learners. The educator directs the student, then the student moves with his/her internal motivation to achieve the desired goal.

Learning at this time seems like authoritarian learning. Students can only follow what is assigned by the teacher without being able to talk much. Students become passive and become accustomed to it so that students find it difficult to try to learn actively and have difficulty in exploring their interests and talents. Each student certainly has different interests and talents. These differences are rarely understood by teachers, making them run the learning according to what they think. This is in line to learn from the viewpoint of humanistic that is to humanize human beings. Humanizing human education is the process of guiding, developing, and directing the basic human potential both physical and spiritual in a balanced manner with respect for other humanistic values (Supriyadi, 2011).

Especially in the current condition where coronavirus disease (covid-19) is spreading or known as coronavirus. Lessons from different levels are shifted to online or online learning. The transfer of learning that is usually done in classrooms into online learning initially sounds so fun and encouraging for students, but it turns out that the implementation is not in line with these expectations. It's not the fun learning students get, it's monotonous learning with mountainous piles of tasks that they have to 


\section{A. Syahid Robbani; Ahmad Muzayyan Haqqy}

complete in a relatively short period. Even students are confused because the assignment not only comes from one subject or course but comes from several subjects/courses simultaneously. Students seem to be made helpless, unable to say anything and required to complete what their teacher has assigned. Inevitably, this unconsciously begins to erode students' motivation in learning, fading their hopes of achieving their coveted learning goals.

Previously, there have been many studies on the theory of learning humanism. "Humanistic Learning Theory In Improving Student Learning Achievement" written by Abd. Qodir stated that if the theory of learning humanistic has been implemented, then students are expected to be able to improve their learning achievements by trying to achieve self-actualization as well as possible (Qodir, 2017). Dewi Latifah in her study entitled "Theory of Learning and Application in Arabic Language Learning" states that in Arabic language learning, humanism theory views students as educated subjects while teachers as facilitators and students are expected to be free human beings, not bound by the views of others and responsibly organize themselves (Latifah, 2016). Firman Sidik in his study entitled "Humanist Education and Its Implications in Learning" states that the existence of learning that is more focused on human values will make every individual (both teacher and student) no longer have to be someone else because it behaves following what is desired (Sidik, 2016). Maimunah in her study "Humanistic Based Arabic Language Learning" mentions several models of humanistic-based Arabic language learning that can be applied in the classroom namely open language education (providing opportunities for students to move freely with teachers acting as mentors), learning to speak cooperatively, and self-learning (Maimunah, 2016).

This article attempts to examine the theory of learning humanism and then examine its implications in Arabic language learning. This study is a literature study and uses a qualitative descriptive approach. Literature 
studies are studies conducted by collecting data from various works of literature, both in libraries and in other places (Mahmud, 2011).

\section{B. Result and Discussion}

\section{Theory of Learning Humanism}

Learning is an activity carried out by an individual to gain intelligence and/or master a science. By learning, one can read and write, can distinguish which is right and which is wrong.

Experts have their definitions of learning according to their respective areas of expertise. According to Surya as quoted by Tohiri, learning to process an individual to obtain a new behavior change as a whole, as a result of the individual's own experience in interaction in his environment. In line with Surya's definition of learning definition, Slameto and Ali stated that learning is an effort made by the individual to obtain a new behavior change as a whole, as a result of the individual's own experience in interacting with his environment (Tohirin, 2006). Cronbach argues that learning as an activity is shown by behavior change as a result of experience. According to Howard L. Kingsley, learning is a process by which behavior (in a broad sense) is caused or altered through practice or practice (learning is the process by which behavior - in the broader sense - is originated or changed through practice or training (Jamarah, 2002). According to Witherington, learning is a personality change, manifested as a new response pattern in the form of skills, attitudes, habits, knowledge, and proficiency (Sukamdinata, 2005).

From some of the definitions above, it can be understood that learning is a process/effort/activity carried out by the individual to obtain a change in personality or behavior. These changes can take the form of new skills, attitudes, habits, knowledge, and skills. The change is certainly a change 


\section{A. Syahid Robbani; Ahmad Muzayyan Haqqy}

in the better direction that can be a provision for a person in the face of his life.

Among the current theory of learning is the theory of learning humanism. The theory of humanistic learning and learning is a learning process that comes first and boils down to human beings, everything is based on the value of humanity. A commonly used term is humanizing people (Ningsih, 2005). Humanism emphasizes several points of attention, namely: 1) feelings; including personal emotions and aesthetic appreciation, 2) social relationships; advocating for friendship and cooperation, responsibility, 3) intellect; knowing, thought and understanding, striving hard against anything that interferes with thought practice, 4) self-actuation; investigation for the full realization of one's deepest self qualities (Stevick, 1991).

The humanistic theory emerged in the mid-20th century in reaction to psychodynamic and behavioristic theories. Humanistic theorists believe that human behavior cannot be explained as a result of unconscious conflicts or as simple conditioning. This theory focuses on the importance of subjective and self-direction conscious experiences (Desmita, 2012).

The theory of learning humanism is inseparable from the psychology of humanism that developed around the 1950s. This psychology emerged as a theory that defies psychoanalysis and behavioristic theory. The theory of humanism sees both as "dehumanizing" because they view man as a slave or pawn who is powerlessly controlled by the environment and the past, and has very little ability to direct himself. Freud's theory was criticized for viewing human behavior as being determined by primitive and animalistic impulses. While behavioristic criticized for this theory is too engrossed with his research on animals and analyzing personality fragmentary (Yusuf et al., 2011). However, by no means the three competing elements, each branch of psychology has contributed to an understanding of human thought and 
behavior. It's just that the psychology of humanism emphasizes the study of human beings as a whole (Danim et al., 2010).

Kunto Wijoyo as quoted by Hilmi stated that humanization means humanizing, eliminating the substance, dependency, violence, and hatred of human beings, by fighting three things: dehumanization, aggressiveness, and loneliness (Hilmi, 2012). Dehumanization makes the teacher the main character and the student must accept what the teacher says without being given free wiggle room so that the printed one is not a critical student (Abdillah, 2017). Aggressiveness is a behavior that aims to harm others both physically, verbally, or psychologically. While loneliness is a feeling of dissatisfaction caused by the gap between a cold social relationship and a social relationship owned.

According to the humanistic school, learning is not only a development of cognitive quality but also a process that occurs in the individual involving all parts or domains. The domains in question include cognitive, affective, and psychomotor domains. Thus, it can be known that the goal to be achieved in the learning process is how learners are able to become responsible individuals, attentive to their environment, and have emotional and spiritual maturity (Baharuddin et al., 2015).

In Islam, humanism is meant to humanize people after his duty as the caliph of God on earth. The Qur'an refers to humans with four terms that have different meanings according to their context, namely: Basyar, used to explain that humans are biological beings; An-Nas, used to show that humans are social beings; The Children of Adam, used to explain that man was a rational being; Al-Insan, is used to explain that man is a spiritual being (Arbayah, 2013). Humanism in Islam runs in a line of dialogue between God, man, and its history. If Islam is interpreted in its historical context, it will give rise to the common thread that Islam is nothing but humanitarian advocacy (Hanafi et al., 2007). 
In the application of humanistic theory, the process that is generally passed is: Formulating clear learning objectives, seeking the active participation of students through learning contracts conducted between teachers and students that are clear, honest, and positive. Encourage students to develop their ability to learn and initiative themselves, encourage students to be sensitive and think critically, and interpret the learning process independently. Encourage students to freely express their opinions, choose their choices, do what they want, and take risks from the behavior shown. The teacher accepts the student as is, tries to understand the student's way of thinking, does not judge normatively, but encourages the student to take responsibility for all the risks of the learning process. Provide opportunities for students to progress according to their speed and evaluations are given individually based on student achievement (Thobroni et al., 2013).

The principles of humanistic learning described by Uci Sanusi in his journal are:

1. The desire to learn; students are given the opportunity and freedom to satisfy their curiosity, to satisfy their interests, and to discover what is important and meaningful about the world around it.

2. Meaningful learning; learning will have meaning and meaning if what is learned is relevant to the needs and intentions of the student. That means that students will learn quickly when what is learned means something to them.

3. Learn without threats; the learning process will run smoothly if students can test their abilities, can try new experiences, or make mistakes without getting censure that usually offends and mentally drops them.

4. Learn for change; the most rewarding learning is learning about the learning process. What is needed now is students who are able to 
study in a changing environment that will continue to change (Sanusi, 2013).

Not much different from the principles of humanistic learning mentioned by Uci Sanusi, Santi Mayasari argues that in the learning process by promoting the philosophy of humanism education, the principles of education are as follows:

1. Students choose what they want to learn. Humanistic teachers believe that students are motivated to study teaching materials, related to their needs and desires

2. Educational objectives to encourage and motivate yourself to learn by yourself

3. Humanistic educators believe, value is irrelevant and only selfevaluation is meaningful

4. Humanistic educators believe in feelings and knowledge. This is in contrast to traditional educators, humanistic teachers do not separate cognitive and affective domains.

5. Humanistic educators emphasize, students should avoid environmental pressures. If students feel safe, the learning process is easier and more meaningful (Mayasari, 2017).

\section{Implications of The Theory of Learning Humanism in Arabic Language}

\section{Learning}

One of the educational problems inherent and allowed to develop in education in Indonesia according to Azyumardi Azra in Samsul Nizar's book is that educational institutions barely provide space for learners to develop their imagination and creativity of cognition, affection, and psychomotor. Worse, he said, the interactions that took place in the school had almost lost their human and personal touch. So, the process of education in schools is almost the same as human interaction in factories that will 


\section{A. Syahid Robbani; Ahmad Muzayyan Haqqy}

produce all-around mechanistic and robotic products (Nizar, 2008). The problem can certainly be solved, one of which is by applying humanist education, namely by formulating clear learning objectives, working on the active participation of learners, encouraging learners to think critically and boldly express opinions, and how a teacher in the learning process tries to understand the student's way of thinking and give them an opportunity.

Some programs that can be applied in the application of humanism in learning are (1) confluent education cooperative learning; education that combines or brings together affective experiences with cognitive learning in the classroom. (2) open education; an educational process that allows students to move freely around the classroom and choose their learning activities. (3) cooperative learning; students work in study groups to assist each other in learning teaching materials. (4) independent learning; a learning process that requires students to be subjects who can design, organize, and control their own activities responsibly (Amir).

With the implementation of this theory of humanism learning in Arabic language learning which is certainly accompanied by models and methods of learning that are in line with and provide religious values both derived from the Qur'an and Hadith or with Mahfuzhat (as a shaper of student personality in order to have humanist souls), students are expected to be individuals who have the academic ability and good character. So that in the future will reduce social problems and deviations such as corruption, inter-student brawls, sexual harassment, theft, trafficking, klitih, free association, drugs, and various other unappreciative behaviors.

When teachers try to understand the students' way of thinking, become facilitators, and understand what students need for learning purposes( need assessment) especially in Arabic language learning, students no longer learn just to find value so that they can be said to pass in the learning. Instead, learn to achieve its goals in learning Arabic, develop its abilities 
both in terms of cognitive, affective, and psychomotor as well as being a responsible individual, and have emotional maturity.

With the implementation of this theory of humanist learning in Arabic language learning, students will be more courageous to express themselves without fear because the teacher positions himself as a facilitator, no longer as an Omnis know-how individual that everything he conveys must be listened to and done by the students. No more aggressive behavior by teachers that has the potential to harm their students both physically, verbally, and psychologically. Thus, existing Arabic language learning will be avoided from three things that are the opposite of the theory of humanism learning as mentioned earlier, namely dehumanization, aggressiveness, and loneliness. This makes students more motivated to acquire new skills, skills, and wider knowledge of Arabic language learning.

In conditions where learning, especially Arabic language learning, should be diverted to online learning or online learning caused by the coronavirus disease (covid-19) pandemic, teachers are required to design a fun learning, motivate students to learn actively and responsibly, and be able to actualize themselves, not monotonous learning simply by giving students a stack of tasks that seem only as a mere formality, not even necessarily will be assessed and evaluated to the maximum. It is time for teachers to try to allow students to express what kind of learning they want, with teachers positioning themselves as facilitators who continue to guide them to their desired learning goals. The self-actualization referred to herein is following what Abraham Maslow (1962) stated, namely the process of self-development or self-discovery and the blooming of existing or hidden potential to become 'fully human' (Stevick, 1991). 
A. Syahid Robbani; Ahmad Muzayyan Haqqy

\section{Conclusion}

The goal to be achieved according to the theory of learning humanism is how learners are able to become responsible individuals, attentive to their environment, and have emotional and spiritual maturity. This can be obtained by fighting three things that contradict the theory of learning humanism itself, namely dehumanization, aggressiveness, and loneliness.

Educational problems that are often encountered can be solved by applying humanist education, namely by formulating clear learning objectives, working on the active participation of learners, encouraging learners to think critically and boldly express opinions, and how a teacher in the learning process tries to understand the student's way of thinking and give them an opportunity.

With the implementation of humanism learning theory, students are expected to be individuals who have the academic ability and good character so that in the future will reduce problems and social deviations; able to develop their abilities both in terms of cognitive, affective, and psychomotor as well as being responsible individuals and having emotional maturity and being able to actualize themselves; students become more motivated to acquire new skills, skills and wider knowledge in Arabic language learning. 
Theory of Learning Humanism and Its Implications in...

\section{References}

Abdillah, Rijal. 2017. "Analisis Teori Dehumanisasi Pendidikan Paulo Freire". Jurnal Aqidah dan Filsafat Islam, Vol. 2 No. 1

Amir, M. Aplikasi Teori Humanisme dalam Kegiatan Pembelajaran, www. kompasiana.com/amirazhar/5528f7cbf17e6188258b4581/aplikasiteori-humanisme-dalam-kegiatan-pembelajaran

Arbayah. 2013. "Model Pembelajaran Humanistik", Jurnal Dinamika Ilmu Vol. 13. No. 2

Baharuddin and Esa, Wahyuni. 2015. Teori Belajar dan Pembelajaran. Yogyakarta: Ar-Ruz Media

Danim, Sudarwan \& Khairil. 2010. Psikologi Pendidikan (Dalam Persepektif Baru). Bandung: Alfabeta

Desmita. 2012. Psikologi Perkembangan Peserta Didik Panduan bagi Orang Tua dan Guru dalam Memahami Psikologi Anak Usia SD, SMP, dan SMA. Bandung: PT Remaja Rosdakarya

Hanafi, Hasan et al. 2007. Islam dan Humanisme: Aktualisasi Humanisme Islam di Tengah Krisis Humanisme Universal. Yogyakarta: IAIN Walisongo Semarang dan Pustaka Pelajar

Hilmi. 2012. "Pendekatan Humanistik Dalam Belajar". Jurnal Kompetensi Vol. 6 No. 2

Jamarah, Syaiful Bahri. 2002. Psikologi Belajar. Jakarta: Rineka Cipta

Latifah, Dewi. 2016. "Teori Belajar dan Penerapannya dalam Pembelajaran Bahasa Arab". Malang: Prosiding Konferensi Nasional Bahasa Arab II, Oktober

Mahmud. 2011. Metode Penelitian Pendidikan. Bandung: Pustaka Setia

Maimunah. 2016. "Pembelajaran Bahasa Arab Berbasis Humanistik". Jurnal Medina-Te, Vol. 14 No. 1 
A. Syahid Robbani; Ahmad Muzayyan Haqqy

Mayasari, Santi. 2017. "Filsafat Pendidikan Humanisme dalam Perspektif Pembelajaran Bahasa Inggris Bagi Peserta Didik di Tingkat Sekolah Menengah Atas: Sebuah Kajian Teori”. Prosiding Dosen Universitas PGRI Palembang Edisi 12

Ningsih, Asri Budi. 2005. Belajar dan Pembelajaran. Jakarta: Rineka Cipta Qodir, Abd. 2017. "Teori Belajar Humanistik dalam Meningkatkan Prestasi Belajar Siswa". Jurnal Pedagogik Vol. 04 No. 02

Sanusi, Uci. 2013. "Pembelajaran dengan Pendekatan Humanis (Penelitian Pada MTs Negeri Model Cigugur Kuningan)". Jurnal Pendidikan Agama Islam- Ta'lim Vol. 11 No. 2

Sidik, Firman. 2016. "Pendidikan Humanis dan Implikasinya dalam Pembelajaran. Jurnal Tadbir Vol. 4 No. 1

Stevick. 1991. Humanism in Language Teaching. New York: Oxford University Press

Sukamdinata, and Nana Syaodih. 2005. Landasan Psikologi Proses Pendidikan. Bandung: Remaja Rosdakarya

Supriyadi, Ende. 2011. Pendidikan dengan Pendekatan Humanistik. Cianjur: TP

Nizar, Samsul. 2008. Memperbincangkan Dinamika Intelektual dan Pemikiran Hamka Tentang Pendidikan Islam. Jakarta: Kencana Thobroni, Muhammad dan Mustofa, Arif. 2013. Belajar dan Pembelajaran: Pengembangan Wacana dan Praktik Pembelajaran dalam Pembangunan Nasional. Yogyakarta: Ar-Ruzz Media

Tohirin. 2006. Psikologi Pembelajaran Pendidikan Agama Islam. Jakarta: Raja Grafindo Persada

Yusuf LN, Syamsu \& Nurihsan, Juntika. 2011. Teori Kepribadian. Bandung: RemajaRosdakarya 